\title{
Effects of adding different dietary levels of guar meal on productive performance of laying hens
}

\author{
S. M. Hassan \\ Animal and Fish Production Department, King Faisal University, Al-Hassa, 31982, Kingdom of Saudi Arabia.
}

Accepted 31 May, 2013

\begin{abstract}
This study was set up to evaluate the effect of different dietary levels of guar meal (GM) on productive performance of laying hens. One hundred and eighty 25-weeks-old Hisex laying hens were randomly distributed among 5 treatments with 6 replicates of 6 hens each. Hens were fed layer diets supplemented with either $\mathbf{0 . 0}, 2.5,5.0,10.0$ or $20.0 \%$ GM for 8 weeks trail period ( 25 to 33 weeks). Body weight, mortality rate, body weight gain, egg production, feed consumption, feed conversion ratio, egg weight, egg mass, egg specific gravity, Haugh unit and egg yolk color were recorded. The results obtained in the present study showed that final body weight and body weight gain were significantly the lowest in hens fed 10.0 and $20.0 \%$ GM when compared with the other treatments, but no significant differences were noticed among hens fed either $0.0,2.5,5.0$, or $10.0 \%$ GM. Mortality rate was significantly higher in hens fed $\mathbf{0 . 0} \%$ GM than those fed $\mathbf{5 . 0}$ or $\mathbf{2 0 . 0 \%}$ GM, but no differences were observed between hens fed either 2.5 or $10.0 \%$ GM and the other treatments. Hens fed $20.0 \%$ GM showed significantly the lowest egg number and percentage produced, feed consumption, egg weight, and egg mass per hen when compared with the remaining treatments. However, hens fed 20.0\% GM exhibited the highest feed conversion ratio and egg specific gravity when compared with the other treatments. Hens fed 5.0 and $\mathbf{1 0 . 0 \%}$ GM produced eggs with more yellowness values than those fed $0.0 \% \mathrm{GM}$, but there were no differences between hens fed either 2.5 or $20.0 \% \mathrm{GM}$ and the other treatments. We conclude that GM can be added into diet up to $10.0 \%$ without adverse effects on productive performance of laying hen.
\end{abstract}

Key words: Egg Production, performance, guar meal, laying hens.

\section{INTRODUCTION}

Using unconventional cheap local feed ingredient alternatives to replace traditional expensive feed ingredients in poultry diets has become of a major economical interest for poultry nutritionists worldwide. Guar, Cyamopsis tetragonoloba L. (syn. C. psoraloides) or cluster bean is a drought-tolerant summer annual legume native to India and Pakistan (Patel and McGinnis, 1985).

Guar bean (GB) consists of three fractions namely endosperm rich in guar gum (GG), germ rich in crude protein and hull or husk rich in crude fiber. Guar meal $(G M)$ is a by-product of the isolation of GG from GB. GM consists of a mixture of germ and hull fractions (Lee et al., 2003).
GM contains about 33.0 to $47.5 \%$ crude protein on a dry matter basis (Ambegaokar et al., 1969; Nagpal et al., 1971; Lee et al., 2004), about 13.0 to $18.0 \%$ residual GG (Anderson and Warnick, 1964; Nagpal et al., 1971; Hansen et al., 1992; Lee et al., 2004) and about 5.0 to $13.0 \%$ crude saponin by weight on a dry matter basis (Curl et al., 1986; Hassan et al., 2010).

Verma and McNab (1984b) reported that approximately $88.0 \%$ of the nitrogen content in GM was true protein, with an argnine content approximately twice that of soybean meal, although more methionine and lysine are needed for optimal rat growth (VanEtten et al., 1961; Verma and 
McNab, 1984b). Gutierrez et al. (2007) reported that GM in USA was sold at about half the price of soybean meal, making it an appealing potential source of protein in animal feed.

GM is rarely used as a feed ingredient in poultry diets because of several anti-nutritional factors such as saponin (Thakur and Pradhan, 1975a, b) and residual GG (Vohra and Kratzer, 1964a, b; 1965; Katoch et al., 1971). However, Couch et al. (1967) recognized trypsin inhibitor as an important anti-nutritional factor in feed ingredients. These findings were contradicted by Lee et al. (2004) who noted that GM contained lower levels of trypsin inhibitor than processed soybean meal.

These anti-nutritional factors have been reported to cause diarrhea, depressed growth rate, and increased mortality in broiler (Sathe and Bose, 1962; Couch et al., 1967; Thakur and Pradhan, 1975a, b; Verma and McNab, 1982; Patel and McGinnis, 1985) and decrease egg production and feed efficiency of laying hens (Nagra et al., 1985; Nagra and Virk, 1986; Ehsani and Torki, 2010). Severe reduction in egg production and stopping of laying of eggs were recorded by Zimmermann et al. (1987) who added 10.0 and $15.0 \% \mathrm{GM}$ in laying hen diets to induce a force molting to improve post molting laying performance.

Residual GG, a highly viscous galactomannan polysaccharide consisting of a $\beta$-1 $\rightarrow 4$ - linked D-mannopyranose backbone with branched $\alpha$ - $1 \rightarrow 6$-D-galactopyranose, is probably the primary factor responsible for the reported illness (Vohra and Kratzer, 1964a, b; 1965; Katoch et al., 1971; Verma and McNab, 1982; Lee et al., 2003), although other anti-nutritional factors such as saponins (Verma and McNab, 1984a; Curl et al., 1986, Hassan et al., 2010) and polyphenols (Bajaj et al., 1978; Kaushal and Bhatia, 1982) have been reported to cause liver, kidney and intestinal damage in mice and rats (Berman et al., 1995; Diwan et al., 2000), and trypsin inhibitor (Brocher and Ackerson, 1950).

It is not yet clear which percentage of GM could be added to laying hen diets without adverse effects on their productive performance. No data is available in the scientific literature directly comparing the effects of adding different dietary levels of $\mathrm{GM}$ in a single laying hen's trial during the early phase laying hens production. Previous investigations evaluating the effects of feeding GM on laying hen performance were carried out on latephase laying hens' production (Saxena and Pradhan, 1974; Verma and McNab, 1984b; Patel and McGinnis, 1985; Nagra and Virk, 1986). Therefore, this study was carried out to evaluate the effects of adding different dietary levels of $\mathrm{GM}(0.0,2.5,5.0,10.0$ and $20.0 \%)$ during the early phase ( 25 to 33 weeks of age) of laying hens on their productive performance.

\section{MATERIALS AND METHODS}

Commercial GM powder was purchased from Rama Industries, Manufacturer \& Exporter of GG Split \& Powder Government Recognized Export House, Gujarat, India.

\section{Experimental design}

A completely randomized design experiment using a total of 180 laying hens (Hisex, 25-wk-old) with similar body weight was conducted. Hens were weighed and randomly distributed in battery group cages $\left(50 \times 30 \times 30 \mathrm{~cm}^{3}\right)$ among five treatments with six replicates of six hens per replicate in a close sided laying hen house. Hens were fed either with a nonguar control diet, or 1 of 4 diets containing $2.5,5.0,10.0$ or $20.0 \%$ GM over a period of 8 weeks ( 25 to 33 weeks). The layer diets used in this study were calculated to be isocloric and isonitrogenus with an average of 2813 Kcal metabolizable energy per $\mathrm{kg}$ of feed and $18.04 \%$ crude protein (Table 1). Feed and water were provided to all laying hens ad libitum. All hens received a 16L: 8D photo program for the duration of the experiment.

\section{Measurements}

Individual body weight of laying hens was measured at the beginning ( $25 \mathrm{wk}$ ) and the end of the experiment (33 wk). Overall mortality rate, egg number and percentage produced per hen, feed consumption, and feed conversion ratio as grams of total feed consumption per hen/total egg mass per hen were recorded from 25 to 33 weeks. Eggs produced during the last 3 consecutive days of each 2 weeks were individually weighed to the nearest $0.01 \mathrm{~g}$ to measure egg weight, total egg mass, egg specific quality, yolk color and Haugh unit for each replicate.

Collected eggs were stored overnight in the same room before egg specific gravity was determined. Egg specific gravity was determined using the floating method (Harms et al., 1990), in which solutions of specific gravity $(1.060$ to $1.10 \mathrm{~g} / \mathrm{mL})$ were used to determine specific gravity in increments of 0.005 . Albumen height was measured with an Ames micrometer (model S-6428, Ames, Waltham, MA) at a point halfway between the yolk and the edge of the widest expanse of albumen. Haugh units were calculated as follows:

Haugh unit $=100 \times \log \left(\mathrm{H}+7.57-1.7 \mathrm{~W}^{0.37}\right)$

Where $\mathrm{H}$ is albumin height $(\mathrm{mm})$ and $\mathrm{W}$ is egg weight (Panda, 1996). The yolk color of eggs was measured using Roche color fan.

\section{Statistical analysis}

The experiment was modeled as a completely randomized design experiment. Data obtained were subjected to one-way ANOVA using the GLM procedure of a statistical software package (SPSS 18.0, SPSS Inc., Chicago, IL). Experimental units were based on cage averages. Treatment means were expressed as mean \pm standard error of means (Mean \pm SEM) and separated $(P \leq 0.05)$ using the Duncan's multiple range test (Duncan, 1955).

\section{RESULTS}

The results obtained from the present study indicated that initial body weight of laying hens distributed among the five dietary treatments was not significantly different at the start of the experiment ( 25 weeks). The final body weight (33 weeks) and the body weight gain ( 25 to 33 weeks) of hens fed a diet containing 10.0 and $20.0 \%$ GM weighed significantly less than those fed a diet containing $0.0,2.5$ or $5.0 \%$ GM. However, there were no significant differences in the final body weight and the body weight gain noticed among hens fed $0.0,2.5,5.0$ or $10.0 \%$ GM. 
Table 1. Composition experimental diets ${ }^{1}$.

\begin{tabular}{|c|c|c|c|c|c|}
\hline \multirow[b]{3}{*}{ Ingredients (\%) } & \multicolumn{5}{|c|}{ Dietary treatment } \\
\hline & \multicolumn{5}{|c|}{ Guar meal (GM) level } \\
\hline & 0.0 & 2.5 & 5.0 & 10.0 & 20.0 \\
\hline Corn & 46.45 & 47.35 & 45.50 & 44.35 & 44.45 \\
\hline Guar meal ${ }^{2}$ & 0.00 & 2.50 & 5.00 & 10.00 & 20.00 \\
\hline Soybean meal (44\%) CP & 36.00 & 31.50 & 32.00 & 28.00 & 16.60 \\
\hline Fish meal $60 \% \mathrm{CP}$ & 3.00 & 4.60 & 2.60 & 2.20 & 4.00 \\
\hline Corn Oil & 4.00 & 3.70 & 4.06 & 4.60 & 4.50 \\
\hline Limestone & 8.50 & 8.50 & 8.50 & 8.50 & 8.50 \\
\hline Dicalcium $\mathrm{PO}_{4}$ & 0.80 & 0.60 & 1.09 & 1.10 & 0.70 \\
\hline DL-Methionine & 0.10 & 0.10 & 0.10 & 0.10 & 0.10 \\
\hline Salt & 0.40 & 0.40 & 0.40 & 0.40 & 0.40 \\
\hline Trace minerals $^{3}$ & 0.25 & 0.25 & 0.25 & 0.25 & 0.25 \\
\hline Vitamins $^{4}$ & 0.40 & 0.40 & 0.40 & 0.40 & 0.40 \\
\hline Antioxidant & 0.10 & 0.10 & 0.10 & 0.10 & 0.10 \\
\hline
\end{tabular}

${ }^{1}$ Calculated analysis of the diets was as follows: CP, $18.04 \%$; ME, 2,813 kcal $/ \mathrm{kg}$; Ca, 3.75\%; non-phytin P, $0.40 \%$; methionine, $0.44 \%$; lysine, $1.25 \%$; threonine, $0.77 \%$; tryptophan, $0.28 \%$. ${ }^{2}$ The guar meal nutrient matrix used was $\mathrm{CP}$, $39.75 \%$; ME, $2,033 \mathrm{kcal} / \mathrm{kg}$; Ca, $0.16 \%$; non-phytin $\mathrm{P}, 0.16 \%$; methionine, $0.45 \%$; lysine, $1.64 \%$; arginine, $4.90 \%$; threonine, $1.04 \%$; and tryptophan $0.43 \%$. ${ }^{3}$ Trace minerals premix added at this rate yields: $149.60 \mathrm{mg} \mathrm{Mn}, 16.50 \mathrm{mg}$ $\mathrm{Fe}, 1.70 \mathrm{mg} \mathrm{Cu}, 125.40 \mathrm{mg} \mathrm{Zn}, 0.25 \mathrm{mg} \mathrm{Se}, 1.05 \mathrm{mg} \mathrm{I}$ per kg diet. ${ }^{4}$ Vitamin premix added at this rate yields: $11,023 \mathrm{IU}$ vitamin $\mathrm{A}, 46 \mathrm{IU}$ vitamin $\mathrm{E}, 3,858 \mathrm{IU}$ vitamin $\mathrm{D}_{3}, 1.47 \mathrm{mg}$ minadione, $2.94 \mathrm{mg}$ thiamine, $5.85 \mathrm{mg}$ riboflavin, $20.21 \mathrm{mg}$ pantothenic acid, $0.55 \mathrm{mg}$ biotin, $1.75 \mathrm{mg}$ folic acid, $478 \mathrm{mg}$ choline, $16.50 \mu \mathrm{g}$ vitamin $\mathrm{B}_{12}, 45.93 \mathrm{mg}$ niacin, and 7.17 mg pyridoxine per kg diet.

Although, mortality rate recorded from 25 to 33 weeks was significantly higher in hens fed the diet containing $0.0 \%$ GM versus those fed 5.0 or $20.0 \%$ GM, there were no significant differences observed between hens fed $0.0 \%$ GM and those fed 2.5 and $10.0 \%$ GM (Table 2).

Results obtained in the present study showed that egg number and percentage produced per hen from 25 to 33 weeks in hens fed $10.0 \%$ GM were significantly more than those fed 0.0 or $20.0 \% \mathrm{GM}$, but were not different from hens fed 2.5 and $5.0 \%$ GM. Hens fed a diet containing $20.0 \%$ GM consumed less feed versus the remaining treatments, but no significant differences were noticed among hens fed either $0.0,2.5,5.0$ or $10.0 \% \mathrm{GM}$. In contract, significant increase in feed conversion ratio was noticed in the $20.0 \%$ GM group ascompared to the remaining GM dietary treatments, but no significant differences were exhibited among hens fed 0.0, 2.5, 5.0 or $10.0 \%$ GM (Table 2 ).

With regards to the effect of feeding GM on the external egg quality with respect to egg weight, total egg mass and egg specific gravity, hens fed a diet containing $20.0 \%$ GM produced the lowest egg mass when compared with the other treatments, whereas no significant differences were observed between hens fed $2.5 \% \mathrm{GM}$ and those fed $0.0,5.0$ and $10.0 \%$ GM. However, hens fed a diet containing $20.0 \%$ GM produced the smallest egg weight with the highest egg specific gravity when compared with the remaining treatments, but no significant differences were observed among hens fed GM at levels less than
$20.0 \%$ (Table 2).

With regards to the effect of feeding GM on the internal egg quality in respect to Haugh unit and egg yolk color, there were no significant differences in Haugh units among all treatments. However, the yellowness values of the egg yolk produced from hens fed 5.0 and $10.0 \%$ GM were significantly higher than those fed $0.0 \% \mathrm{GM}$, but no significant differences were observed between hens fed 2.5 or $20.0 \%$ GM and those fed $0.0,5.0$ and $10.0 \%$ GM (Table 2).

\section{DISCUSSION}

This study was set up to evaluate which percentage of GM could be added into laying hen diets during early phase (25 to 33 weeks of age) without adverse effects on the productive performance of laying hens. The results obtained from the present study were in agreement with the observations of Zang (2004) who found that feeding $10.0 \%$ GM increased body weight loss of laying hens. Also, Gutierrez et al. (2007) noted that feeding GM at a level higher than $5.0 \%$ retarded the growth of laying hens. Anderson and Warnick (1964) and Lee et al. (2003) reported no significant negative impacts on the body weight of broiler chicks fed a diet supplemented with $5.0 \% \mathrm{GM}$.

Several studies reported that GM use in poultry diets historically was limited by its adverse effects on body 
Table 2. Effect of adding different dietary levels $(0.0,2.5,5.0,10.0$ or $20.0 \%)$ of guar meal (GM) on productive performance of laying hens from 25 to 33 weeks of age

\begin{tabular}{|c|c|c|c|c|c|}
\hline \multirow{2}{*}{ Age (week) } & \multicolumn{5}{|c|}{ GM levels } \\
\hline & $0.0 \%$ & $2.5 \%$ & $5.0 \%$ & $10.0 \%$ & $20.0 \%$ \\
\hline & \multicolumn{5}{|l|}{ Initial body weight (g) } \\
\hline \multirow[t]{2}{*}{25} & $1540.50 \pm 4.04$ & $1559.83 \pm 17.14$ & $1540.17 \pm 23.33$ & $1552.50 \pm 10.14$ & $1539.17 \pm 14.30$ \\
\hline & \multicolumn{5}{|c|}{ Overall final body weight (g) } \\
\hline \multirow[t]{2}{*}{33} & $1546.50^{a} \pm 26.28$ & $1577.67^{\mathrm{a}} \pm 32.17$ & $1548.00^{a} \pm 33.21$ & $1455.17^{b} \pm 33.99$ & $1417 \cdot 17^{b} \pm 16.51$ \\
\hline & Mortality rate (\%) & & & & \\
\hline \multirow[t]{2}{*}{$25-33$} & $11.11^{\mathrm{a}} \pm 3.51$ & $8.33^{\mathrm{ab}} \pm 3.73$ & $0.00^{b} \pm 0.00$ & $5.56^{\mathrm{ab}} \pm 3.51$ & $0.00^{b} \pm 0.00$ \\
\hline & Body weight gain (g & & & & \\
\hline \multirow[t]{2}{*}{$25-33$} & $6.00^{\mathrm{a}} \pm 0.12 .34$ & $17.83^{\mathrm{a}} \pm 36.38$ & $7.83 .^{a} \pm 25.82$ & $-97.33^{b} \pm 41.23$ & $-125.00^{b} \pm 21.08$ \\
\hline & Egg number produc & d/hen & & & \\
\hline \multirow[t]{2}{*}{$25-33$} & $45.21^{b} \pm 1.92$ & $47.31^{\mathrm{ab}} \pm 3.01$ & $50.75^{\mathrm{ab}} \pm 1.73$ & $53.27^{\mathrm{a}} \pm 0.97$ & $30.83^{\mathrm{C}} \pm 1.92$ \\
\hline & Percentage of egg $p$ & oduced/ hen & & & \\
\hline \multirow[t]{2}{*}{$25-33$} & $80.72 .^{b} \pm 3.44$ & $84.48^{\mathrm{ab}} \pm 5.37$ & $90.63^{\mathrm{ab}} \pm 3.09$ & $95.13^{\mathrm{a}} \pm 1.73$ & $55.06^{\mathrm{c}} \pm 3.43$ \\
\hline & Feed consumption ( & feed/ hen) & & & \\
\hline \multirow[t]{2}{*}{$25-33$} & $5901.56^{\mathrm{a}} \pm 121.87$ & $5627.89^{a} \pm 162.64$ & $5570.17^{\mathrm{a}} \pm 60.79$ & $5627.75^{a} \pm 66.64$ & $4801.00^{b} \pm 154.87$ \\
\hline & Feed conversion rat & o ( $g$ feed consumed & egg mass produce & & \\
\hline \multirow[t]{2}{*}{$25-33$} & $2.28^{b} \pm 0.07$ & $2.05^{b} \pm 0.12$ & $1.88^{b} \pm 0.05$ & $1.83^{b} \pm 0.05$ & $3.08^{a} \pm 0.30$ \\
\hline & Egg weight (g) & & & & \\
\hline \multirow[t]{2}{*}{$25-33$} & $57.73^{\mathrm{a}} \pm 0.62$ & $60.15^{a} \pm 0.40$ & $59.93^{\mathrm{a}} \pm 0.67$ & $59.14^{\mathrm{a}} \pm 0.97$ & $53.70^{b} \pm 0.50$ \\
\hline & Egg mass (g/hen) & & & & \\
\hline \multirow[t]{2}{*}{$25-33$} & $2655.49^{b} \pm 118.56$ & $2844.10^{\mathrm{ab}} \pm 177.45$ & $3040.07^{\mathrm{a}} \pm 101.09$ & $3149.82^{a} \pm 53.67$ & $1659.59^{\mathrm{C}} \pm 113.93$ \\
\hline & Egg specific gravity & & & & \\
\hline \multirow[t]{2}{*}{$25-33$} & $1.083^{b} \pm 0.00$ & $1.085^{b} \pm 0.00$ & $1.085^{b} \pm 0.00$ & $1.085^{b} \pm 0.00$ & $1.088^{\mathrm{a}} \pm 0.00$ \\
\hline & Haugh unit & & & & \\
\hline \multirow[t]{2}{*}{$25-33$} & $87.30 \pm 2.12$ & $85.31 \pm 1.93$ & $90.29 \pm 1.75$ & $88.91 \pm 1.67$ & $88.87 \pm 1.40$ \\
\hline & Yolk color & & & & \\
\hline $25-33$ & $3.25^{b} \pm 0.25$ & $3.79^{a b} \pm 0.23$ & $4.21^{a} \pm 0.25$ & $4.00^{a} \pm 0.30$ & $3.83^{\mathrm{ab}} \pm 0.25$ \\
\hline
\end{tabular}

${ }^{\mathrm{a}-\mathrm{c}}$ Means \pm standard error of mean (means \pm SEM) within a row that do not share a common superscript are significantly different $(P \leq 0.05)$.

weight gain (Saxena and Pradhan, 1974; Thakur and Pradhan, 1975a, b). While Lee et al. (2005) reported that GM could be safely fed to broilers at $2.5 \%$ of the diet without adversely affecting performance; the findings of Saxena and Pradhan (1974) showed that GM has deleterious effects on body weight gain of broiler chicks.

Previous studies reported that the negative effects of adding GM high levels in poultry diets on body weight might be attributed to the presence of anti-nutrient factors such as saponins (Thakur and Pradhan, 1975a, b) and residual GG (Vohra and Kratzer, 1964a; 1965; Katoch et al., 1971; Saxena and Pradhan, 1974; Thakur and Pradhan, 1975a, b; Annison and Choct, 1991; Lee et al., 2005) by increasing the viscosity of the digesta (Blackburn and Johnson, 1981). It was reported that GM contains about 5.0 to $13.0 \%$ crude guar saponin (Curl et al., 1986; Hassan et al., 2010) and about 13.0 to $18.0 \%$ residual GG on a dry matter basis (Anderson and Warnick, 1964; Nagpal et al., 1971; Lee et al., 2004).

The growth depressing properties of residual GG found in GM used in poultry diets may be removed by treating the feed with enzymes capable of hydrolyzing it, namely pectinase and cellulase, a preparation from sprouted GB (Vohra and Kratzer, 1964a) or endo- $\beta$-D-mannanase (Vohra and Kratzer, 1964a; 1965; Verma and McNab, 1982; Patel and McGinnis, 1985; Lee et al., 2003). These exogenous enzymes are thought to reduce intestinal viscosity and to alleviate the deleterious effects associated with excessive GG by delaying gastric emptying and increasing small intestinal transit time, hence inhibiting the absorption of nutrients (Blackburn and Johnson, 1981). Results obtained in the present study showed a significant effect of adding GM into laying hen diets on mortality rate. However, Hassan et al. (2008) found no significant effect on mortality rate when adding GM in broiler diet rate. Other reports mentioned that adding GM in broiler diets increased mortality rate (Sathe and Bose, 1962; Anderson and Warnick, 1964; Thakur and Pradhan, 1975b; Verma and McNab, 1982; Patel and McGinnis, 1985).

The results obtained in the present study with respect to feed consumption were in agreement with the findings 
of Gutierrez et al. (2007) who noted that adding 2.5 to $5.0 \%$ GM to laying hen diets did not decrease the feed consumption, but were in disagreement with the observations of Zang (2004) who found that feeding 10.0\% GM depressed feed consumption of laying hens. However, Thakur and Pradhan (1975a, b) reported that using high level of GM in poultry diets historically was limited by its adverse effects on feed consumption.

The high feed conversion ratio observed in hens fed $20.0 \% \mathrm{GM}$ as compared to the remaining treatments were in agreement with several studies that reported that adding high levels of GM in broiler and laying hen diets showed deleterious effects on feed conversion ratio (Saxena and Pradhan, 1974; Nagra et al., 1985; Patel and McGinnis, 1985; Nagra and Virk, 1986; Lee et al., 2003).

Several studies observed that the interior and exterior quality of eggs was not deliriously affected by GM feeding (Couch et al., 1967; Saxena and Pradhan, 1974; Patel and McGinnis, 1985; Zimmermann et al., 1987). Also, Soleimani et al. (2011) noted that $6.0 \%$ GM can be fed to the laying hen diets without adverse effects on productive performance. Shahbazi (2012) noted that adding 2.5 to $5.0 \%$ GM to laying hen diets did not affect Haugh unit.

However, Gutierrez et al. (2007) reported that GM can be added to laying hens diets up to $5.0 \%$ without harmful effects on laying hens performance including egg production, Haugh unit and egg specific gravity. They found significant differences in egg weight and egg mass in laying hens fed 2.5 and 5.0\% GM. In contrast, Ehsani and Torki (2010) noted that adding GM to laying hen diets at level more than $3.0 \%$ decreased productive performance.

While Couch et al. (1967) observed that 10.0\% GM did not affect egg weight; Zang (2004) found that feeding $10.0 \%$ GM did not affect egg weight but decreased the egg yolk color and Haugh unit. Also, he noted that feeding $15.0 \%$ GM severely depressed egg production. The results obtained in the present study suggested that GM can be incorporated into high-production laying hen diets at a level up to $10.0 \%$ without deleterious effects on egg production. Also, Nageswara and Ramasubba (2002) concluded that toasted GM up to $10.0 \%$ can be included in layer duck diet.

Gutierrez et al. (2008) found that feeding laying hens diets containing $20.0 \%$ GM significantly reduced productive performance of laying hens, whereas Verma and McNab (1982) indicated that adding GM up to $20.0 \%$ to laying Japanese quail diets could replace groundnut meal without affecting the egg number or egg weight.

In the present study, after 8 weeks dietary treatment period (25 to 33 weeks), egg yolk from hens fed diets containing 5.0 or $10.0 \%$ GM consistently had higher egg yolk yellowness color values than hens fed $0.0 \% \mathrm{GM}$, which indicates that the factors responsible for egg yolk yellowness color values may be distributed differently in GM. The results obtained in the present study were in disagreement with the findings of Gutierrez et al. (2007) who observed no significant differences in egg yolk color when feeding laying hens on diet containing up to $5.0 \%$ GM. In contrast, Verma and McNab (1984b) reported that egg yolk color index decreased with the inclusion of GM in laying diet. Thus, the mode of action of GM on egg yolk color is still unclear and more research is required to clarify this phenomenon.

It is not yet clear whether residual GG or another compound in GM such as saponin are responsible for the main anti-nutritional compounds in GM that contribute to its growth inhibitory effects impacting on body weight and body weight gain up to $10.0 \%$ GM or feed consumption and feed conversion ratio up to level less than $20.0 \%$. GG residue in diet containing $20 \%$ GM might be most likely responsible for the adverse effect on productive performance of laying hens due to the fact that hens fed diets containing larger quantities of GM subsequently contain more quantity of $G G$ residue as compared to the amount lower than $20.0 \%$ concentration of GM. Therefore, further research investigations are required to explain this phenomenon.

\section{Conclusions}

We conclude that GM can be fed to laying hens at levels up to $10.0 \%$ without adverse effects on their productive performance with respect to egg production, feed consumption, feed conversion ratio, egg weight, egg mass, egg specific gravity, yolk color and mortality. However, the final body weight and body weight gain reduced as compared to laying hens fed GM at levels lower than $10.0 \%$ and this may be economically feasible for lowering feed cost by maintaining laying hen performance.

\section{ACKNOWLEDGEMENT}

The author expresses his sincere thanks to Deanship of Scientific Research of the King Faisal University for funding this project.

\section{REFERENCES}

Ambegaokar SD, Kamath JK, Shinde VP (1969). Nutritional studies in protein of 'gawar' (Cyamopsis tetragonoloba). J. Nutr. Diet. 6:323328.

Anderson JO, Warnick RE (1964). Value of enzyme supplements in rations containing certain legume seed meals or gums. Poult. Sci. 43:1091-1097.

Bajaj KL, Rani M, Arora YK (1978). Polyphenols and lignins of mature guar pods (Cyamopsis tetragonoloba L. Taub.). Plant Biochem. J. 5:140-145.

Berman E, Schlicht M, Moser VC, Macphail RC (1995). A multidisciplinary approach to toxicological screening. 1. Systemic toxicity. J. Toxicol. Environ. Health 45:127-143.

Blackburn NA, Johnson IT (1981). The effect of guar gum on the viscosity of the gastrointestinal contents and on glucose uptake from the perfused jejunum in the rat. Br. J. Nutr. 46: 2: 239-46.

Brocher R, Ackerson CW (1950). The nutritive value of legume seeds. Effect of autoclaving and trypsin inhibitor test for seventeen species. J. Nutr. 41:339-345.

Couch JR, Lazano JA, Creger CR (1967). Soy protein guar meal and 
excess calcium in nutrition of commercial layers. Poult. Sci. 46:1248.

Curl CL, Price KR, Fenwick GR (1986). Isolation and structural elucidation of a triterpenoid saponin from guar, Cyamopsis tetragonoloba. Phytochemistry 25:2675-2676.

Diwan FH, Abdel-Hassan IA, Mohammed ST (2000). Effect of saponin on mortality and histopathological changes in mice. East. Mediterr. Health J. 6:345-351.

Duncan DB (1955). Multiple ranges and multiple $F$ test. Biometrics 11:142.

Ehsani M, Torki M (2010). Effects of Dietary Inclusion of Guar Meal Supplemented by $\beta$-Mannanase on Performance of Laying Hens, Egg Quality Characteristics and Diacritical Counts of White Blood Cells. Am. J. Anim. Vet. Sci. 5: 237-243.

Gutierrez O, Zhang C, Caldwell DJ, Carey JB, Cartwright AL, Bailey CA (2008). Guar Meal Diets as an Alternative Approach to Inducing Molt and Improving Salmonella Enteritidis Resistance in Late-Phase Laying Hens. Poult. Sci. 87:536-540

Gutierrez O, Zhang C, Cartwright AL, Carey JB, Bailey CA (2007). Use of Guar By-Products in High-Production Laying Hen Diets. Poult. Sci. 86:1115-1120

Hansen RW, Byrnes SM, Johnson AD (1992). Determination of galactomannan (gum) in guar (Cyamopsis tetragonolobus) by high performance liquid chromatography. J. Sci. Food Agric. 59:419-421.

Harms RH, Rossi AF, Sloan DR, Miles RD, Christmas RB (1990). A method for estimating shell weight and correcting specific gravity for egg weight in eggshell quality studies. Poult. Sci. 69:48-52.

Hassan SM, Haq AU, Byrd JA, Berhow MA, Cartwright AL, Bailey CA (2010). Haemolytic and antimicrobial activities of saponin-rich extracts from guar meal. Food Chem. 119:600-605.

Hassan SM, El-Gayar AK, Caldwell DJ, Bailey CA, Cartwright AL (2008). Guar meal ameliorates Eimeria tenella infection in broiler chicks. Vet. Parasitol. 157:133-138.

Katoch BS, Chawla JS, Rekib A (1971). Absorption of amino acid (in vitro) through intestinal wall of chicken in presence of guar gum. Ind. Vet. J. 4:142-146.

Kaushal GP, Bhatia IS (1982). A study of polyphenols in the seeds and leaves of guar (Cyamopsis tetragonoloba L. Taub) feed toxicity studies. J. Sci. Food Agric. 33:461-470.

Lee JT, Bailey CA, Cartwright AL (2003). Guar meal germ and hull fractions differently affect growth performance and intestinal viscosity of broiler chickens. Poult. Sci. 82:1589-1595.

Lee JT, Connor-Appleton S, Haq AU, Bailey CA, Cartwright AL (2004). Quantitative measurement of negligible trypsin inhibitor activity and nutrient analysis of guar meal fractions. J. Agric. Food Chem. 20:6492-56495

Lee JT, Connor-Appleton S, Bailey CA, Cartwright AL (2005). Effects of guar meal by-product with and without beta-mannanase Hemicell ${ }^{\circledR}$ on broiler performance. Poult. Sci. 84:1261-1267.

Nageswara AR, Ramasubba RV (2002). Utilization of Toasted Guar Meal and De-Oiled Mustard Cake in Layer Ducks. Ind. J. Anim. Nutr. 19: (4) 346- 352.

Nagpal ML, Agrawal OP, Bhatia IS (1971). Chemical and biological examination of guar-meal (Cyampsis tetragonoloba L.). Ind. J. Anim. Sci. 4:283-293.

Nagra SS, Shingari BK, Ichhponani JS (1985). Feeding of guar (Cyampsis tetragonoloba) meal to poultry.1. Growth of commercial broiler chicks. Ind. J. Poult. Sci. 20:188-193.

Nagra SS, Virk RS (1986). Growth and laying performance of White Leghorn pullets fed toasted guar meal alone or in combination with groundnut and mustard cakes as sources of protein. Ind. J. Poult. Sci. 21:16-20.
Panda PC (1996). Shape and Texture. In Panda PC (ed) Text book on egg and poultry technology, Vikas Publishing House Pvt. Ltd., New Delhi, India. pp. 57.

Patel MB, McGinnis J (1985). The effect of autoclaving and enzyme supplementation of guar meal on the performance of chicks and laying hens. Poult. Sci. 64:1148-1156.

Sathe BS, Bose S (1962). Studies on the utilization of industrial and farm by-products in growing poultry rations. Ind. J. Vet. Sci. 32:7484.

Saxena UC, Pradhan K (1974). Effect of high protein levels on the replacement value of guar meal (Cyamopsis tetragonoloba) in layer's ration. Ind. J. Anim. Sci. 44:190-193.

Shahbazi HR (2012) Dietary inclusion of guar meal supplemented by Bmannanase II) Evaluation egg quality characteristics and blood parameters of laying hens. Glob. Vet. 9:1:67-72.

Soleimani P, Golian A, Tahmasebi A M, Sedghi M (2011). Effect of guar meal as a source of protein on laying hens performance. Vet. J. 4(16):975-985

Thakur RS, Pradhan K (1975a). A note on inclusion of guar meal (Gyamopsis tetragonoloba) in broiler rations. Ind. J. Anim. Sci. 45:98102.

Thakur RS, Pradhan K (1975b). A note on inclusion of guar meal (Gyamopsis tetragonoloba) in broiler rations. Effect on carcass yield and meat composition. Ind. J. Anim. Sci. 45:880-884.

VanEtten CH, Miller RW, Wolff IA, Jones Q (1961). Amino acid composition of twenty-seven selected seed meals. J. Agric. Food Chem. 9:79-82.

Verma SVS, McNab JM (1982). Guar meal in diets for broiler chickens. Br. Poult. Sci. 23:95-105.

Verma SVS, McNab JM (1984a). Chemical, biochemical and microbiological examination of guar meal. Ind. J. Poult. Sci. 19:165170.

Verma SVS, McNab JM (1984b). Performance of hens fed guar meal containing diets with or without supplemental cholesterol. Ind. J. Poult. Sci. 19:245-250.

Vohra P, Kratzer FH (1964a). Growth inhibitory effect of certain polysaccharides for chickens. Poult. Sci. 43:1164-1170.

Vohra P, Kratzer FH (1964b). The use of guar meal in chicken rations. Poult. Sci. 43: 502-503.

Vohra P, Kratzer FH (1965). Improvement of guar meal by enzymes. Poult. Sci. 44:1201-1205.

Zang C (2004). Evaluation of guar meal as a source of prebiotic galactomannans for laying hens. PhD dissertation, Texas A\&M University, College Station, Texas, United States of America. pp. 23 89.

Zimmermann NG, Andrews DK, McGinnis J (1987). Comparison of several induced molting methods on subsequent performance of single comb White Leghorn hens. Poult. Sci. 66: 3:408-417. 